\title{
A checklist of polypores from Northeast China
}

\author{
YU-CHENGDAI
}

DAI, Y.C. 2000: A checklist of polypores from Northeast China. - Karstenia 40: 2329. Helsinki. ISSN 0453-3402.

This paper summarizes the polypores (Basidiomycota) recorded during the investigations made by the author in 1993-1999 in northeastern China. The study is based on ca. 2500 specimens collected, but additional data was obtained from the critical reexamination of the previously collected herbarium material. Altogether 261 polypore species were recorded from the study area and are listed here. Fifteen species are new to China. In addition, nine species found in the Russian Far East are included. The checklist provides a taxonomically sound basis for future studies on poroid woodinhabiting fungi in the area. Taxonomy of some noteworthy species is outlined, and the following new combinations are proposed: Inocutis levis (P. Karst.) Y.C. Dai, Inonotopsis exilispora (Y.C. Dai \& Niemelä) Y.C. Dai, and Trichaptum polycystidiatum (Pilát) Y.C. Dai.

Key words: Basidiomycota, checklist, Northeast China, polypores, taxonomy

Yu-Cheng Dai, Botanical Museum (Mycology), P.O. Box 47, FIN-00014 University of Helsinki, Finland

\section{Introduction}

The checklist of polypores from Changbai was published in 1996 (Dai 1996), and species in the paper were found from the Changbai Mountain Range only, which is located mostly in Jilin Province. After this publication, three additional field trips were made in Jilin and other provinces of NE China, and the number of species has rapidly increased from these trips. It is therefore necessary to compile a more complete list of polypores from the whole of Northeast China. In the previous reports (Dai 1996, 1997, 1998; Langer \& Dai 1998) 10 species were described from the study area.

\section{Material and methods}

In the present study the polypores recorded in the provinces of Heilongiiang, Jilin, Liaoning, and the eastern Inner Mongolia Autonomous Region are listed. The field work was carried out by the author in 1993-1999, and the data derive from both forest reserves and unprotected managed forests. In addition, the species found in the Beijing area were included. Altogether, nearly 2500 specimens were collected during the field trips. Additional data was obtained by critical re-rexamination the previously collected material in the herbaria HMAS (Beijing, China), HBNNU (Changchun, China), IFP (Shenyang, China), NEFI (Harbin, China), and O (Oslo, Norway). However, species reported from NE China (Tai 1979, Li 1991, Pan 1995) without voucher specimens were excluded from the present study.

Nearly 200 specimens, collected from the Russian Far East (deposited in TAA, Tartu, Estonia), were examined, and most of the species from this material were also found from the Chinese side of the border. Although some species have not yet been recorded in NE China, they are included here.

\section{Results and discussion}

A total of 261 species were recorded. Fifteen species are new to China. In addition, 7 species belonging to Antrodia P. Karst., Antrodiella Ryvarden \& Johans., Ceriporiopsis Domański, Junghuhnia Corda. emend. Ryvarden, Postia P. Karst., and Spongipellis Pat., were collected but 
no existing names could be found for them. These species were excluded from the present paper, and they will be described later in forthcoming publications. The present checklist provides a taxonomically sound basis for future studies on poroid wood-inhabiting fungi in the area. In the following the polypores newly reported from China are in bold, and the species found in the Russian Far East but not yet in NE China are marked with an asterisk (*). A few species were treated collectively, and they are indicated with sensu lato. The definition of polypores in this paper is used in broad sense, and so includes the Polyporaceae, Ganodermataceae, and poroid species of the Hymenochaetaceae, Corticiaceae and Tremellaceae. Some species were identified preliminarily and indicated with "cf.", because the Chinese collections are not totally identical to the authentic material of these species, or they do not completely fit these species as they were described, or the Chinese material is not in good condition. The author abbreviations of scientific names follow Kirk and Ansell (1992), except for evident misspellings.

\author{
Checklist \\ *Abortiporus biennis (Bull.) Singer \\ Amylocystis lapponica (Romell) Singer \\ Anomoporia albolutescens (Romell) Pouzar \\ Anomoporia bombycina (Fr.) Pouzar \\ Anomoporia flavissima Niemelä \\ Anomoporia myceliosa (Peck) Pouzar \\ Anomoporia vesiculosa Y.C. Dai \& Niemelä \\ Antrodia cf. albida (Fr. : Fr.) Donk \\ Antrodia cf. albobrunnea (Romell) Ryvarden \\ Antrodia carbonica (Overh.) Ryvarden \& Gilb. \\ Antrodia crassa (P. Karst.) Ryvarden \\ Antrodia gossypina (Speg.) Ryvarden \\ Antrodia heteromorpha (Fr. : Fr.) Donk \\ Antrodia infirma Renvall \& Niemelä \\ Antrodia cf. macra (Sommerf.) Niemelä \\ Antrodia macrospora Bernic. \& De Dom. \\ Antrodia malicola (Berk. \& M.A. Curtis) Donk \\ Antrodia primaeva Renvall \& Niemelä \\ Antrodia pulvinascens (Pilát) Niemelä \\ Antrodia serialis (Fr.) Donk \\ Antrodia cf. sinuosa (Romell) P. Karst. \\ * Antrodia sitchensis (Baxter) Gilb. \& Ryvarden \\ Antrodia vaillantii (DC. : Fr.) Ryvarden \\ Antrodia variiformis (Peck) Donk \\ Antrodia xantha (Fr. : Fr.) Ryvarden
}

Antrodiella albocinnamomea Y.C. Dai \& Niemelä Antrodiella americana Ryvarden \& Gilb. Antrodiella citrinella Niemelä \& Ryvarden Antrodiella gypsea (Yasuda) T. Hattori \& Ryvarden

Antrodiella pallasii Renvall, Johannesson \& Stenlid

Antrodiella romellii (Donk) Niemelä sensu lato Antrodiella semisupina (Berk. \& M.A. Curtis) Ryvarden sensu lato

Antrodiella ussurii Y.C. Dai \& Niemelä Aurantioporus fissilis (Berk. \& M.A. Curtis) H. Jahn

Auriporia aurea (Peck) Ryvarden

Bjerkandera adusta (Willd. : Fr.) P. Karst.

Bjerkandera fumosa (Pers. : Fr.) P. Karst.

*Bondarzewia montana (Quél.) Singer

Castanoporus castaneus (Lloyd) Ryvarden

Ceriporia alachuana (Murrill) Hallenb.

Ceriporia excelsa (S. Lundell) Parmasto

Ceriporia purpurea (Fr.) Donk

Ceriporia cf. spissa (Schwein. : Fr.) Rajchenb.

Ceriporia tarda (Berk.) Ginns

Ceriporia viridans (Berk. \& Broome) Donk

Ceriporiopsis aneirina (Sommerf. : Fr.)

Domański

Ceriporiopsis cf. balaenae Niemelä

*Ceriporiopsis cremea (Parmasto) Ryvarden

Ceriporiopsis gilvescens (Bres.) Domański

Ceriporiopsis mucida (Pers. : Fr.) Gilb. \& Ryvarden

Ceriporiopsis resinascens (Romell) Domański

Cerrena unicolor (Bull. : Fr.) Murrill

Chaetoporellus latitans (Bourdot \& Galzin) Singer

Climacocystis cf. borealis (Fr.) Kotl. \& Pouzar

Coltricia perennis (L. : Fr.) Murrill

Cryptoporus volvatus (Peck) Shear

Cyclomyces xeranticus (Berk.) Y.C. Dai \& Niemelä

Daedalea dickinsii Yasuda

Daedaleopsis confragosa (Bolton : Fr.) J.

Schroet.

Daedaleopsis sinensis (Lloyd) Y.C. Dai

Daedaleopsis tricolor (Bull. : Mérat) Bondartsev \& Singer

Datronia mollis (Sommerf.) Donk

Datronia scutellata (Schwein.) Gilb. \& Ryvarden

Datronia stereoides (Fr.) Ryvarden

Dichomitus campestris (Quél.) Domański \& Orlicz

Dichomitus squalens (P. Karst.) D.A. Reid 
Diplomitoporus flavescens (Bres.) Domański Diplomitoporus lindbladii (Berk.) Gilb. \& Ryvarden

Donkioporia expansa (Desm.) Kotl. \& Pouzar Elmerina holophaea (Pat.) Parmasto

Fomes fomentarius (L. : Fr.) Fr.

Fomitiporia hartigii (Allesch. \& Schnabl) Fiasson \& Niemelä

Fomitiporia punctata (P. Karst.) Murrill

Fomitiporia robusta (P. Karst.) Fiasson \& Niemelä

Fomitopsis cajanderi (P. Karst.) Kotl. \& Pouzar Fomitopsis cf. meliae (Underw.) Gilb. \& Ryvarden

Fomitopsis officinalis (Vill. : Fr.) Bondartsev \& Singer

Fomitopsis pinicola (Sw. : Fr.) P. Karst.

Fomitopsis rhodophaea (Lév.) Imazeki

Fomitopsis rosea (Alb. \& Schwein. : Fr.) P. Karst.

Funalia cervina (Schwein. : Fr.) Y.C. Dai

Funalia trogii (Berk.) Bondartsev \& Singer

Ganoderma lipsiense (Batsch) G.F. Atk.

Ganoderma lucidum (W. Curtis. : Fr.) P. Karst.

Ganoderma subumbraculum Imazeki

Ganoderma tsugae Murrill

Gelatoporia pannocincta (Romell) Niemelä

Gloeophyllum abietinum (Bull. : Fr.) P. Karst.

Gloeophyllum carbonarium (Berk. \& M.A. Cur-

tis) Ryvarden

Gloeophyllum odoratum (Wulfen : Fr.) Imazeki

* Gloeophyllum protractum (Fr.) Imazeki

Gloeophyllum sepiarium (Wulfen : Fr.) P. Karst.

Gloeophyllum trabeum (Pers. : Fr.) Murrill

Gloeoporus dichrous (Fr. : Fr.) Bres.

Grifola frondosa (Dicks. : Fr.) Gray

Hapalopilus croceus (Pers. : Fr.) Bondartsev \& Singer

Hapalopilus rutilans (Pers. : Fr.) P. Karst.

Haploporus odorus (Sommerf.) Bondartsev \&

Singer

Heterobasidion insulare (Murrill) Ryvarden

Heterobasidion parviporum Niemelä \& Korho-

nen

Hexagonia apiaria Pers. : Fr.

Hyphodontia syringae E. Langer

Inocutis rheades (Pers.) Fiasson \& Niemelä

Inocutis tamaricis (Pat.) Fiasson \& Niemelä

Inonotopsis exilispora (Y.C. Dai \& Niemelä) Y.C.

Dai

Inonotopsis subiculosa (Peck) Parmasto Inonotus andersonii (Wll. \& Everh.) Cerny Inonotus hispidus (Bull. : Fr.) P. Karst.
Inonotus obliquus (Pers. : Fr.) Pilát

Inonotus pruinosus Bondartsev

Inonotus radiatus (Sowerby : Fr.) P. Karst

Irpex lacteus (Fr. : Fr.) Fr. sensu lato

Ischnoderma benzoinum (Wahlenb. : Fr.) P.

Karst.

Ischnoderma resinosum (Fr.) P. Karst.

Jahnoporus hirtus (Cooke) Nuss

Junghuhnia collabens (Fr.) Ryvarden

Junghuhnia fimbriatella (Peck) Ryvarden

Junghuhnia nitida (Pers. : Fr.) Ryvarden

Junghuhnia pseudoziligiana (Parmasto) Ryvar-

den

Laetiporus sulphureus (Bull. : Fr.) Murrill

Lenzites acutus Berk.

Lenzites betulinus (L. : Fr.) Fr.

Leucophellinus irpicoides (Pilát) Bondartsev \& Singer

Loweporus pubertatis (Lloyd) T. Hattori

*Megasporoporia cf. setulosa (Henn.) Rajchenb.

Melanoporia castanea (Yasuda) T. Hattori \& Ryvarden

Meripilus giganteus (Pers. : Fr.) P. Karst.

Microporus cf. subaffinis (Lloyd) Imazeki

Nigroporus ussuriensis (Bondartsev \& Ljub.)

Y.C. Dai \& Niemelä

Oligoporus balsameus (Peck) Gilb. \& Ryvarden

Oligoporus cf. floriformis (Quél. ex Bres.) Gilb. \&

Ryvarden

Oligoporus lowei (Pilát) Gilb. \& Ryvarden

Oligoporus obductus (Berk.) Gilb. \& Ryvarden

Oligoporus rennyi (Berk. \& Broome) Donk

Oligoporus sericeomollis (Romell) Bondartseva

Onnia leporina (Fr.) H. Jahn

Onnia tomentosa (Fr.) P. Karst.

Onnia triquetra (Lenz) Imazeki

Oxyporus bucholtzii (Bondartsev \& Ljub.) Y.C.

Dai \& Niemelä

Oxyporus corticola (Fr.) Ryvarden

Oxyporus cf. latemarginatus (Dur. \& Mont. ex

Mont.) Donk

Oxyporus obducens (Pers. : Fr.) Donk

Oxyporus populinus (Schumach. : Fr.) Donk

Oxyporus sinensis X.L. Zeng

Parmastomyces mollissimus (Maire) Pouzar

Parmastomyces taxi (Bondartsev) Y.C. Dai \& Niemelä

Perenniporia fraxinea (Bull. : Fr) Ryvarden

Perenniporia japonica (Yasuda) T. Hattori \& Ryvarden

Perenniporia cf. fergusii Gilb. \& Ryvarden 
Perenniporia maackiae (Bondartsev \& Ljub.) Parmasto

Perenniporia medulla-panis (Jacq. : Fr.) Donk Perenniporia narymica (Pilát) Pouzar

Perenniporia ochroleuca (Berk.) Ryvarden Perenniporia robiniophila (Murrill) Ryvarden Perenniporia subacida (Peck) Donk

Perenniporia tenuis (Schw.) Ryvarden var. tenuis Perenniporia truncatospora (Lloyd) Ryvarden Phaeolus schweinitzii (Fr. : Fr.) Pat.

Phellinidium aciferum Y.C. Dai

Phellinidium ferrugineofuscum (P. Karst.) Fiasson \& Niemelä

Phellinidium sulphurascens (Pilát) Y.C. Dai

Phellinus baumii Pilát

Phellinus chinensis Pilát

Phellinus conchatus (Pers. : Fr.) Quél.

Phellinus ferreus (Pers.) Bourdot \& Galzin

Phellinus ferruginosus (Schrad. : Fr.) Pat.

Phellinus cf. gilvoides (Lloyd) Imazeki

Phellinus gilvus (Schwein. : Fr.) Pat.

Phellinus igniarius (L. : Fr.) Quél. sensu lato

Phellinus cf. laevigatus (P. Karst.) Bourdot \&

Galzin

Phellinus cf. laricis (Jaczewski in Pilát) Pilát

Phellinus lundellii Niemelä

Phellinus nigrolimitatus (Romell) Bourdot \& Galzin

Phellinus cf. pini (Brot. : Fr.) A. Ames

Phellinus tremulae (Bondartsev) Bondartsev \&

Borisov

Phellinus tuberculosus (Baumg.) Niemelä

Phellinus vaninii Ljub.

Phellinus viticola (Schwein. : Fr.) Donk

Phellinus yamanoi (Imazeki) Parmasto

Phylloporia ribis (Schumach. : Fr.) Ryvarden

Physisporinus rivulosus (Berk. \& M.A. Curtis)

Ryvarden

Physisporinus sanguinolentus (Alb. \& Schwein.

: Fr.) Pilát

Physisporinus vitreus (Pers. : Fr.) P. Karst.

Physisporinus xylostromatoides (Bres.) Y.C. Dai

Piptoporus betulinus (Bull. : Fr.) P. Karst.

Piptoporus quercinus (Schrad.) Pilát

Piptoporus soloniensis (Dubois : Fr.) Pilát

Polyporus admirabilis Peck

Polyporus arcularius Batsch : Fr.

Polyporus badius (Pers. : Gray) Schwein.

Polyporus brumalis Pers. : Fr.

Polyporus ciliatus Fr. : Fr.

Polyporus hemicapnodes Berk. \& Broome

Polyporus mongolicus (Pilát) Y.C. Dai
Polyporus mori (Pollini : Fr.) Fr.

Polyporus pekingensis J.D. Zhao \& L.W. Xu

*Polyporus pseudobetulinus (Pilát) Thorn, Kotir. \& Niemelä

Polyporus squamosus (Huds. : Fr.) Fr.

Polyporus tubaeformis (P. Karst.) Ryvarden \& Gilb.

Polyporus tuberaster Jacq. : Fr.

*Polyporus vassilievae Thorn

Polyporus varius Pers. : Fr.

Poriodontia subvinosa Parmasto

Postia caesia (Schrad. : Fr.) P. Karst.

Postia fragilis (Fr. : Fr.) Jülich

Postia guttulata (Peck) Jülich

Postia lactea (Fr. : Fr.) P. Karst.

Postia leucomallella (Murrill) Jülich

Postia pileata (Parmasto) Y.C. Dai \& Renvall

Postia placenta (Fr.) M.J. Larsen \& Lombard

Postia cf. rancida (Bres.) M.J. Larsen \& Lombard

Postia simanii (Pilát) Jülich

Postia stiptica (Pers. : Fr.) Jülich

Postia cf. subcaesia (A. David) Jülich

Postia undosa (Peck) Jülich

Pouzaroporia subrufa (Ellis \& Dearn.) Vampola

Protomerulius caryae (Schwein.) Ryvarden

Pycnoporellus fulgens (Fr.) Donk

Pycnoporus cinnabarius (Jacq. : Fr.) P. Karst.

Pycnoporus sanguineus (L. : Fr.) Murrill

Pyrrhoderma scaura (Lloyd) Ryvarden

Rigidoporus crocatus (Pat.) Ryvarden

Rigidoporus eminens Y.C. Dai

Schizopora cystidiata A.D. David \& Rajchenb.

Schizopora flavipora (Cooke) Ryvarden

Schizopora paradoxa (Schrad. : Fr.) Donk

Schizopora radula (Pers. : Fr.) Hallenb.

Skeletocutis amorpha (Fr. : Fr.) Kotl. \& Pouzar

Skeletocutis biguttulata (Romell) Niemelä

Skeletocutis brevispora Niemelä

Skeletocutis carneogrisea A. David

Skeletocutis kuehneri A. David

Skeletocutis lenis (P. Karst.) Niemelä

Skeletocutis nivea (Jungh.) Jean Keller

Skeletocutis ochroalba Niemelä

Skeletocutis odora (Sacc.) Ginns

Skeletocutis perennis Ryvarden

Skeletocutis stellae (Pilát) Jean Keller

Skeletocutis subvulgaris Y.C. Dai

Skeletocutis vulgaris (Fr.) Niemelä \& Y.C. Dai

Spongipellis delectans (Peck) Murrill

Spongipellis spumeus (Sowerby : Fr.) Pat.

Stromatoscypha fimbriata (Pers. : Fr.) Donk

Trametes conchifer (Schwein. : Fr.) Pilát

Trametes gibbosa (Pers. : Fr.) Fr. 
Trametes hirsuta (Wulfen : Fr.) Pilát

*Trametes ljubarskyi Pilát

Trametes ochracea (Pers.) Gilb. \& Ryvarden

Trametes pubescens (Schumach. : Fr.) Pilát

Trametes suaveolens (Fr. : Fr.) Fr.

Trametes velutina (Fr. : Fr.) G. Cunn.

Trametes versicolor (L. : Fr.) Pilát

Trechispora candidissima (Schwein.) Bondartsev \& Singer

Trechispora hymenocystis (Berk. \& Broome)

K.H. Larsson

Trechispora mollusca (Pers. : Fr.) Liberta

Trichaptum abietinum (Pers. : Fr.) Ryvarden

Trichaptum fuscoviolaceum (Ehrenb. : Fr.) Ryvarden

Trichaptum laricinum (P. Karst.) Ryvarden

Trichaptum pargamenum (Fr.) G. Cunn.

Trichaptum cf. perrottetii (Lév.) Ryvarden

Trichaptum polycystidiatum (Pilát) Y.C. Dai

Tyromyces chioneus (Fr.) P. Karst.

Tyromyces cf. sibiricus Penzina \& Ryvarden

Wolfiporia dilatohypha Ryvarden \& Gilb.

Wolfiporia curvispora Y.C. Dai

Wrightoporia avellanea (Bres.) Pouzar

Wrightoporia lenta (Oveh. \& J. Lowe) Pouzar

Wrightoporia rubella Y. C. Dai

\section{Notes on selected species}

Antrodia macrospora was reported from Italy only (Bernicchia 1990). Several specimens were collected on Quercus mongolica from NE China but because most of them were sterile, this taxon was not reported before. However, in 1998 fertile material was collected, and it proved to be identical to Antrodia macrospora. The spores in the Chinese material are 12-14 $\times 4-5.5 \mu \mathrm{m}$, which are slightly smaller than those in the Italian material of $A$. macrospora $(12-18 \times 3.5-6 \mu \mathrm{m})$.

Antrodiella pallasii was recently described from North Europe (Johannesson et al. 2000). It often grows on fallen trunks of Picea, which had previously been decayed by Trichaptum spp. One Chinese specimen was treated as $A$. romellii (Dai 1996), but it inhabits in rotten wood of Picea which was evidently decomposed by Trichaptum sp. Its pore surface is pale yellowish, and its spores are broadly ellipsoid, (2.7-)2.9-3.3 (-3.7) $\times(1.8-) 1.9-2.1(-2.2) \mu \mathrm{m}(\mathrm{n}=30 / 1)$. The Chinese material has slightly shorter spores, but is otherwise identical to the collections of $A$. pallasii from Finnish Lapland.
Antrodiella romellii sensu lato: The Chinese material is certainly not Antrodiella romellii as this name used in Europe. It grows together with a species of Phellinus Quél. on rotten wood of poplar. Its pore surface is pale yellowish, so it is therefore somewhat similar to that of A. pallasii, but its spores are broadly ellipsoid, and they are closer to $A$. romellii. In addition, the hyphae at bottom of tubes are amyloid in the Chinese collection, and this character has not been found in any species of Antrodiella.

Heterobasidion parviporum was recently separated from H. annosum (Fr.) Bref. sensu lato (Niemelä \& Korhonen 1998), and it represents the well known $\mathrm{S}$ type of $H$. annosum. The Chinese isolates are completely interfertile with European isolations of S type, but totally intersterile with stocks of $\mathrm{P}$ type, which mainly grows on Pinus (Dai \& Korhonen 1999). The P type in Europe is $H$. annosum sensu stricto. In addition, the mating frequency of Chinese stocks ( $H$. parviporum) with the European F group is up to $94 \%$, but these matings were usually unilateral. The $\mathrm{F}$ group, which is distributed in southern Europe, was recently described as $H$. abietinum (Niemelä \& Korhonen 1998).

Hexagonia apiaria has been widely reported from tropical Asia (Corner 1987, Zhao \& Zhang 1992, Quanten 1997). The collection from Jilin Province is so far the northernmost record of this species. The large and hexagonal pores $(2-4$ per $\mathrm{cm})$ distinguish the species.

Phellinus cf. gilvoides: Several specimens collected on angiosperms are treated here under Phellinus cf. gilvoides. This taxon is similar to $P$. viticola, but the latter species usually grows on gymnosperms, and it has fairly large pores (4-5 per $\mathrm{mm}$ vs. $5-7$ per $\mathrm{mm}$ in $P$. cf. gilvoides). My material of $P$. cf. gilvoides is mostly sterile, and spores were found in a single collection. The spores are hyaline, thin-walled, and cylindric, $5.5-6.5 \times 1.7-2.2 \mu \mathrm{m}$, so they are different from the allantoid spores of $P$. viticola. $P$. gilvoides was described from Florida, USA, and Ryvarden (1992) considered it to be $P$. viticola. However, the spores in the type material were reported to be hyaline to pale yellowish brown, 7.7-8.5 × 3.5$4.5 \mu \mathrm{m}$ (Larsen \& Cobb-Poulle 1990).

Phellinus cf. gilvoides is distributed in Japan, too. Hattori (pers. comm.) has made an intensive study on it, and he will soon describe it as a new species. 
Polyporus pekingensis was originally described from Beijing area (Zhao et al. 1982). Its holotype (HMAS 19416) was studied. It is composed by several connected pilei, and forms a large funnel-shaped and rosettiform fruit body. It is evidently fully grown basidiocarp, but its hyphal system is distinctly monomitic, and the hyphae are acyanophilous. So it does not belong to the genus Polyporus P. Micheli ex Adans. : Fr. sensu stricto. Its new combination and detailed description will be given in a later publication.

Skeletocutis brevispora was described from the boreal forest of North Europe (Niemelä 1998), and it grows in rich, dense and old-growth spruce forest. Skeletocutis brevispora usually inhabits the wood decayed by Phellinidium ferrugineofuscum. The cylindric spores with a distinct tapering apiculus are the best characters for recognizing this species in the microscope. The single Chinese specimen was collected from a fallen trunk of spruce in virgin forest of Changbaishan Nature Reserve, and its ecology in NE China is very similar to that in Europe.

Skeletocutis ochroalba: The Chinese collection is the second record of this species after its description from North Canada (Niemelä 1985). It grows on fallen trunks of Picea in virgin forests, and seems to be a very rare species. Skeletocutis ochroalba is very similar to $S$. nivea in the microscope, but the latter species has abundant encrustations on its hyphae at dissepiment edges, and it usually grows on angiosperms.

Tyromyces cf. sibiricus was recently described from Siberia (Penzina \& Ryvarden 1998). Some Chinese specimens were previously identified as T. cf. subgiganteus (Berk. \& M.A. Curtis) Ryvarden (Dai 1996). After carefully checking my material, it turned out to be closer to T. sibiricus. Its pores are 5-8 per $\mathrm{mm}$, and its spores are more or less ellipsoid with a large guttule, (4.4-)5-6($6.5) \times 4-5(-5.2) \mu \mathrm{m}, \mathrm{L}=5.55 \mu \mathrm{m}, \mathrm{W}=4.49 \mu \mathrm{m}$, $\mathrm{Q}=1.24(\mathrm{n}=30 / 1)$. T. sibiricus has globose spores, $4.5-5 \mu \mathrm{m}$ in diameter, and its pores are relatively large ( $4-5$ per $\mathrm{mm})$. For the time being I treat my collections as $T$. cf. sibiricus.

\section{New combinations}

Inonotopsis exilispora (Y.C. Dai \& Niemelä) Y.C. Dai, comb. nov. - Basionym: Inonotus exilispora Y.C. Dai \& Niemelä, Mycotaxon 55: 275, 1997.

In the present paper species in Inonotus P. Karst. sensu lato were transferred into the homogeneous genera Inocutis Fiasson \& Niemelä, Inonotopsis Parmasto, Inonotus sensu stricto, and Onnia P. Karst. Inonotus s.str. only includes the species which have setae, and thick-walled and coloured spores, but lacks a contextual core. Inonotopsis exilispora was originally described under the genus Inonotus s.l. (Dai et al. 1997), and it has hyaline and thin-walled spores. Therefore it is more closely related to Inonotopsis rather than Inonotus.

Inocutis levis (P. Karst.) Y.C. Dai, comb. nov. Basionym: Inonotus levis P. Karst., Hedwigia 26: 112, 1887 (lectotype in $\mathrm{H}$, studied).

Inonotus levis P. Karst. was reported from western China (Dai et al.1997), and it is characterized by a distinct basal core, thick-walled and yellowish brown spores, and by the absence of setae. So it evidently belongs to Inocutis, so the above combination is proposed.

Trichaptum polycystidiatum (Pilát) Y.C. Dai, comb. nov. - Basionym: Poria polycystidiata Pilát., Bull. Soc. Mycol. France, 49: 277, 1934 (holotype, PRM 498237, studied).

This species was originally described from Amur District in the Russian Far East (Pilát 1934), and it was re-described as Hirschioporus quercinus Parmasto (Parmasto \& Parmasto 1987). The types of both names, collected on Quercus mongolica, were studied, and they are identical.

Acknowledgements: I thank the curators of the herbaria of HMAS, HBNNU, IFP, NEFI, O, and TAA for the loans of specimens. Financial support from the Academy of Finland (Project No. 44173, 1998-2000) is gratefully acknowledged. Drs. Pertti Renvall (Kuopio, Finland ) and Greg Thorn (Wyoming, USA) reviewed the manuscript. The Botanical Museum of the University of Helsinki has arranged excellent working facilities. Special thanks are due to Dr. Tuomo Niemelä (Helsinki) and Mr. Guo-Fu Qin (Shenyang, China) for companionship during the field trips. 


\section{References}

Bernicchia, A. 1990: Polyporaceae s.1. in Italia. - Pat. Vegetale, Bologna. 594 pp.

Corner, E.J.H. 1987: Ad Polyporaceas 4. The genera Daedalea, Flabellophora etc. - Beih. Nova Hedwigia 86: $1-265$.

Dai, Y.C. 1996: Changbai wood-rotting fungi 7. A checklist of the polypores. - Fung. Sci. 11: 79-105.

Dai, Y.C. 1997: Polypore flora and diversity in Changbai Mts., northeastern China. - Publ. Bot. Univ. Helsinki 25: 1-25 + 101 pp. Yliopistopaino, Helsinki.

Dai, Y.C. 1998: Changbai wood-rotting fungi 9. Three new species and other species in Rigidoporus, Skeletocutis and Wolfiporia (Basidiomycota, Aphyllophorales). - Ann. Bot. Fennici 35: 143-154.

Dai, Y.C. \& Korhonen, K. 1999: Heterobasidion annosum group $\mathrm{S}$ identified in north-eastern China. - European J. For. Path. 29: 273-279.

Dai, Y.C., Niemelä, T. \& Zang, M. 1997: Synopsis of the genus Inonotus (Basidiomycetes) sensu lato in China. - Mycotaxon 55: 273-283.

Johannesson, H., Renvall, P. \& Stenlid, J. 2000: Taxonomy of the genus Antrodiella (Basidiomycetes) inferred from morphological and molecular data. Mycol. Res. 104: 92-99.

Kirk, P.M. \& Ansell, A.E. 1992: Authors of fungal names. - Index of fungi suppl.: 1-95.

Langer, E. \& Dai, Y.C. 1998: Changbai wood-rotting fungi 8 . Hyphodontia syringae sp. nov. - Mycotaxon 67: 181-190.

Larsen, M.J. \& Cobb-Poulle, L.A. 1990: Phellinus (Hymenochaetaceae). A survey of the world taxa. - Synopsis Fungorum 3: 1-206.

Li, R.G. 1991: The fungiflora of Jilin Province. Northeastern Normal Univ. Press, Chuangchun. 528 pp. (In Chinese).
Niemelä, T. 1985: Mycoflora of Poste-de-la-Baleine, Northern Quebec. Polypores and the Hymenochaetales. - Naturaliste Canadien 112: 445-472.

Niemelä, T. 1998: The Skeletocutis subincarnata complex (Basidiomycetes), a revision. - Acta Bot. Fennica 161: 1-35.

Niemelä, T. \& Korhonen, K. 1998: Taxonomy of the genus Heterobasidion. - In: Woodward, S., Stenlid, J., Karjalainen, R. \& Rüttermann, A. (eds.), Heterobasidion annosum: Biology, Ecology, Impact and Control, pp. 27-33. C.A.B. International, Oxon.

Pan, X.R. 1995: Macrofungi of Xiaoxingan Mts. Northeast Forestry Univ. Press, Harbin. 258 pp. (In Chinese)

Parmasto, E. \& Parmasto, I. 1987: Variation of basidiospores in the Hymenomycetes and significance to their taxonomy. - Bibl. Mycol. 115: 1-168.

Penzina, T. \& Ryvarden, L. 1998: Tyromyces sibiricus nov. sp. - Folia Cryptog. Estonica 33: 109-110.

Pilát, A. 1934 (1933): Additamenta ad floram Sibriae Asiaeque orientalis mycologicam. - Bull. Soc. Mycol. France 49: 256-339.

Quanten, E. 1997: The polypores (Polyporaceae s.1.) of Papua New Guinea. - Opera Bot. Belgica 11: 1-352.

Ryvarden, L. 1992: Type studies in the Polyporaceae 23. Species described by C.G. Lloyd in Lenzites, Polystictus, Poria and Trametes. - Mycotaxon 44: 127-136.

Tai, F.L. 1979: Sylloge fungorum Sinicorum. - Science Press, Beijing. 1527 pp. (In Chinese).

Zhao, J.D. \& Zhang, X.Q. 1992: The polypores of China. - Bibl. Mycol. 145: 1-524.

Zhao, J.D., Xu, L.W. \& Zhang, X.Q. 1982: Taxonomic study on the Polyporaceae in China. - Acta Microbiol. Sinica 22: 218-232. 